\author{
プーチン大統領の再登板と「反体制派」の時代 \\ ——政治体制の正統性をめぐる攻防—— \\ 油 本 真 理 \\ (北海道大学スラブ・ユーラシア研究センター助教)
}

\title{
Struggle over the Regime Legitimacy in Russia: Putin's Return and the Rise of Opposition
}

\author{
Aburamoto, Mari \\ Assistant Professor, Slavic-Eurasian Research Center, Hokkaido University
}

\begin{abstract}
This article revisits the beginning of Putin's third term, which was characterized by the rise of opposition. Here the opposition means "non-systemic opposition," who placed itself decisive opposition to the regime. One of the most prominent opposition activist was Alexei Navalny. Following the 2011 Duma election, the opposition gained power with the activation of post-election protest movements "For Fair Elections." Since the protest movements soon declined, many researchers focused more on the regime's coercive measures towards the opposition. However, it is no less important to ask why the opposition gained power and remained active for a while. This article explores the reason behind the rise of opposition, and reveals how the regime reacted to the opposition's activities. In answering these questions, this article focuses on the regime's effort to defend its legitimacy from the opposition's attacks.

The article first explores why the opposition gained power. The answer can be found in the opposition's active commitment to the politicization of regime legitimacy. Such topics include electoral integrity, distribution of power, corruption and others. The early example of the opposition's commitment to the legitimacy issue was their initiatives in anti-corruption campaigns. Corruption issue became a trigger for the opposition's further attack on the regime legitimacy. In addition, it should not be ignored that the opposition's attack on the regime legitimacy well suited to a populist discourse. The opposition emphasized how the regime contradicts the interests of ordinary people, for example, by committing electoral fraud, contradicting the "rule of law," or committing illegal enrichment. The regime had difficulty in refuting the opposition's criticism.

Second, the article traces how the regime reacted to the opposition's attacks. At first, the regime tried to discredit the opposition by mobilizing anti-western rhetoric and strengthening the patriotic mobilization. But the regime's attempts had limited impact
\end{abstract}

Keywords: regime legitimacy, electoral authoritarianism, non-systemic opposition, post-election protest, populist discourse 
in discrediting the opposition. Then the regime tried to narrow the room for opposition activities by forestalling the opposition's agenda. The regime actively participated in the anti-corruption campaigns, such as banning the high-ranking officials from possessing bank account abroad, and limiting the maximum amount of money for purchase of cars by officials. The regime's active commitment to anti-corruption initiative narrowed the room for opposition activities.

The analysis on the "era of opposition" reveals the importance of discourse-level struggle over the regime legitimacy. Despite its significant disadvantage against the incumbent elites, the opposition could attack the regime by mobilizing the legitimacy issue. In order to avoid the opposition's attacks, the regime could adopt limited measures: after a series of attempts, the regime took over the opposition's agenda and itself began to commit to the legitimacy issue. The experience of Putin's third term provides us with a useful perspective in predicting the future of Russian politics: once the opposition succeeds in mobilizing the legitimacy issue, it will not be easy for the regime to tackle the opposition's attacks.

\section{1 問題の 所 在}

現在の状況から振り返ると既に隔世の感があるが，プーチン大統領第三期目の前半は反体制 派勢力の台頭に特徴付けられた ${ }^{(1)}$ 。これらの勢力は 2011 年下院選挙後の抗議運動の中で力を つけるようになり，2012 年大統領選挙を経て以降も政権との対決を鮮明にした。反体制派勢 力が一定のプレゼンスを示した時期はそれほど長続きしなかったものの ${ }^{(2)}$, 反体制派が一時的 であれ台頭したことは, 現職・与党が圧倒的な優位に立っている近年のロシア政治に括いては 特異なできごとであった。

これまでの研究に招いては, 反体制派の台頭と衰退は抗議運動の隆盛と結びつけて考えられ てきた。もっとも, 抗議運動が比較的短い期間で収束に向かったことから, 研究関心は間もな く政権による抑圧へと移った。この点に関してもっぱら注目されたのが, 政権による反体制派 への抑圧である ${ }^{(3)}$ 。反体制派の活動家らはたびたび拘束され，時には有罪判決を受けることも あった。また，プーチン大統領の就任後は制度上も厳格化が進められた。2012 年 5 月には抗 議運動法の改正が行われ，法律に違反した場合には多額の罰金が科されることになった ${ }^{(4)}$ 。さ らに，NGO やインターネットに対する規制も強められた ${ }^{(5)}$ 。これらの制度変更が反体制活動

(1) 本稿においては，この時期に台頭した勢力を「反体制派」と呼び，議会内の野党とは区別する。2012 年に政党の要件が大幅に引き下げられた結果, それまで議会外で活動していた勢力も政党としての要 件を満たすようになったが，一部の野党勢力は依然として選挙への参加が難しい状況にある。

(2) 反体制派勢力は時間が経過するにつれて少しずつその勢いを失っていき， 2014 年のクリミア併合とそ の後の愛国主義動員の強化は，反体制派の衰退傾向を決定的にした（White 2015）。

(3) Lanskoy and Suthers 2013, Sakwa 2014, Sakwa 2015, Gel'man 2015a.

(4) Федеральный закон от 8 июня 2012 г. N 65-Ф3 “О внесении изменений в Кодекс Российской Федерации об административных правонарушениях и Федеральный закон “О собраниях, митингах, демонстрациях, шествиях и пикетированиях” Российская газета, 9 июня 2012 г. この法改正によっ て，抗議運動の禁止事項が増えたことに加え，法律に違反した場合の罰金は，一般市民に 30 万ルー ブル，公職にある者には 60 万ルーブルとされた。

(5) 詳細については Lanskoy and Suthers (2013), Gel'man (2015a) を参照。 
家による抗議運動の組織を困難にしたことは事実であり, 実際に, 抗議運動は 2012 年中頃に は目に見えて沈静化していった。

しかし, 反体制派は抗議運動の収束とともに姿を消したわけではない。抗議運動が収束して 以降もしばらくの間，反体制派は一定の勢力を維持し続けた。2012 年秋には抗議運動の盛り 上がりの中で台頭した新たな反体制派勢力の合議体として「野党調整評議会」が作られた ${ }^{(6)}$ 。 そして，2013 年秋には反体制派のアレクセイ・ナヴァリヌィがモスクワ市長選挙に出馬し， 現職候補であったセルゲィ・ソビャーニンの次点につけ， $27.2 \%$ を得票している ${ }^{(7)}$ 。政権側に よる反体制派への統制強化に注目するだけでは，反体制派がぞのように台頭し，そして衰退し ていったのかを十分に説明することはできない。

ここに，反体制派がたどった経過をめぐる疑問が生じる。なぜ，反体制派は政権側の抑圧に もかかわらず一定のプレゼンスを維持したのか。そして，いったんは政治の表舞台に躍り出た かに思われた反体制派が次第に精彩を欠いていったのはなぜなのか。この時期の反体制派の動 向を検討したゲリマンは，反体制派が予想外の成功を招さめたがゆえに組織的・戦略的な限界 に直面したと説明している ${ }^{(8)}$ が，その限界がなぜ生じたのかは明らかではない。これらの疑 問を明らかにするため，本稿では，政権側と反体制派との相互関係に注目する。本稿において は，反体制派が政権に対してどのような攻撃を行ったのか，そして，それに対して政権側から いかなるリアクションがあったのかの解明が主たる研究課題となる。

本稿からは，政権側と反体制派との間で，政治体制の正統性をめぐって厳しい応酬が繰り広 げられたことが明らかになる。反体制派が政治体制の正統性に疑義を呈する最もわかりやすい 局面は選挙後の選挙不正疑惑であるが, それ以外にも, 政治権力の配分, 法の支配, 腐敗・污 職などといった幅広い論点が含まれることが指摘されている ${ }^{(9)}$ 。本稿からは，政権にとっては 反体制派からの批判への反論が容易ではなかったこと, しかし, 最終的には, 政権側は自ら反 体制派の批判の構図を取り込むよらになり，それが次第に反体制派の活動領域を狭めていった ことが示される。政権側の取り組みは, 抑圧や規制の強化によっては押さえ込めなかった反体 制派の活動領域を縮小寸ることに貢献したのである。

このよらなアプローチを採用する本稿は，ロシアに拈ける反体制派と政権との一筋縄ではい かない関係をよりよく理解することを可能にする。政権にとってのジレンマは本稿の主要な登 場人物の一人でもあるナヴァリヌィとの関係に見出すことができる。彼が反体制派活動家とし て知名度を上げるにつれ，彼の周囲では次々と疑惑が浮上した。その初期の最も大きな疑惑と なったのが「キーロフ木材」事件である ${ }^{(10)}$ 。各種の疑惑は, 政権がナヴァリヌィをコントロー ルするための有効な手段であった。しかし，これは諸问の剣でもあった。なぜなら，次々と疑 惑が浮上する中で，政権の対決的な姿勢がかえって一般市民からの同情を呼んだ側面もあるた めである ${ }^{(11)}$ 。本稿は, 主に言説のレヴェルに注目し, 政権の正統性に対する批判を加えた反

(6) 調整評議会の選挙は 2012 年 10 月 20 日から 22 日にかけて行われ, 全部で 45 名が選ばれた。もっとも, 意思統一は困難であり，およそ 1 年後にその活動を停止した。貝田 $2016,44$.

(7) モスクワ市長選挙に抢いては，競争的な選挙の実施を重視した現職候補側がナヴァリヌィの出馬を後 押ししたという側面もある。

(8) Gel'man 2015b.

(9) Greene 2002.

(10) ナヴァリヌィには，2009年に「キーロフ木材」の資産を横領したとの疑惑がかけられていた。

(11) これをよく示すのが, モスクワ市長選挙直前の顛末であった。2013 年 7 月 17 日, キーロフ州の裁判所 に拈いてナヴァリヌィに有罪判決が下った。この判決は，被選挙権が失われ，ナヴァリヌィの出馬 
体制派とそれに対する政権側の対処を振り返ることにより，政権が反体制派との関係において 直面したジレンマを描き出そうとするものである。

また，本稿の議論は，ロシアにおいてポピュリスト的な言説が果たす役割をめぐる議論とも 密接に関連している。この時期に打ける反体制派の強さの一つの要因として, 彼らが政権の公 的なディスコースを反転させてポピュリスト的な言説構成をとったことが指摘されている ${ }^{(12)}$ 。 すなわち，この時期の反体制派による政権批判は，一般の人々と政権・政治エリートとを鋭く 対置させ，自らを一般の人々の代弁者と位置付けるものであった。プーチン大統領自身がしば しばポピュリスト的な言説に依拠し，「敵」との対決を前面に打ち出して支持を調達してきた ことは既に指摘されている通りであるが ${ }^{(13)}$, 本稿に执いては, 政権と反体制派の間で繰り広 げられた応酬を振り返ることにより，ロシアに扔いてポピュリスト的な言説が実際にどのよう に用いられたのか，そしてそれが政権执よび反体制派にとっていかなる影響を与えたのかを明 らかにする。

本論に入る前に，プーチン再登板前後の時期を取り扱ら本稿が現状理解にどのように貢献す るのかといら点について言及しておくことにしたい。プーチン再登板後, とりわけクリミア併 合後のロシアにおいては，プーチン大統領の支持率が跳ね上がるに至った。本稿が主要な対象 とする「反体制派の時代」は, ロシア政治が新たな段階に入るにあたって半ば忘れ去られるに 至った。しかし， 2014 年以降の変化は，政権に対する不満や不信感の消滅を意味するとは限 らない。「反体制派の時代」に招いて政権が反体制派の扱いに苦慮した様子を明らかにする本 稿は, プーチン大統領再登板直後の不安定な政治状況がクリミア後にどのよらな変化を遂げた のかを解明するだけでなく, 現在の政治体制が抱える潜在的な弱点に目を向けることを可能に する。

以下，まず第二節において，2011 年下院選挙前後の時期に反体制派がぞのようにして台頭 したのかを明らかにする。その上で, 第三節では, 反体制派による政権批判の構造について考 察する。第四節，第五節では，政権が反体制派からの批判をかわすためにどのようにして対応 を試みたのかを明らかにする。第六節では議論をまとめる。

\section{2 ポスト「タンデム」期における反体制派の台頭}

ロシアに颃いてはプーチン大統領の第一期目，第二期目を経て安定した政治状況が現れるに 至ったが，「タンデム」時代への移行に伴って求心力がやや低下したことに加え，2008 年から 2009年にかけての金融危機の影響を受ける中で, 政府の腐敗やガヴァナンスの非効率性に対す る不満が顕在化するようになった ${ }^{(14)}$ 。腐敗・污職に関しては既にメドヴェージェフ大統領の下 で諸方面にわたる対策が開始されて抢り, 議会内の野党によってもさらなる污職対策の必要性 が訴えられていたが ${ }^{(15)}$ ，こうした不満をらまく代弁したのが, 議会外の反体制派勢力であった。

\footnotetext{
】がかなわなくなることを意味したが, この判決は強い反発を引き起こし, 最終的にナヴァリヌィは選 挙に出馬することになった。

(12) Lassila 2016.

(13) 宇山 2014.

(14) Chaisty and Whitefield 2012.

(15) そのらち重要な問題として挙げられるのが,「腐敗の防止に関する国際連合条約」の批准問題であった。 ロシアは 2006 年 3 月 8 日に同条約を批准したものの, 第 20 条は除外されていた。このことを問題
} 
いわゆる反体制派勢力が人々の不満を代弁するようになった初期の例としては, 2010 年に ボリス・ネムッォフらを含むリベラル派運動の「ソリダールノスチ」が出した「プーチン・総 括・10 年」といら小冊子がある ${ }^{(16)}$ 。この冊子の内容は, ロシアに抢ける腐敗の根深さと, そ こに㧤いてプーチンの取り巻きが果たしている役割を紏弾するものであった。また，この時期 に抢ける腐敗の問題を考学る上では，ナヴァリ又ィの存在に触れないわけにはいかない。それ 以前からブロガーとしての知名度を上げていたナヴァリヌィは2011 年に「反污職基金」を創 設し，政府高官らの污職スキャンダルを暴くようになった。

污職批判は下院選挙が近づくにつれてさらなる拡大の兆しを見せ，選挙にも影響を与えるこ とになる。そのきっかけとなったのは,ナヴァリヌィによる「統一ロシア」批判である。彼は, 「統一ロシア」は「詐欺師と泥棒の党」であるとし, 政権側エリートの腐敗を批判したのである。 この言葉は予想以上に効果的であった ${ }^{(17)}$ 。この表現は瞬く間に人口に膾多しただけでなく, このフレーズを聞いたことがない人も，「詐欺師と泥棒の党」といら表現が「統一ロシア」を 指すといらことにはすぐに察しがついた。「統一ロシア」はプーチン体制のアキレス腱でもあり， 污職批判は，選挙の動向にも影響を与えかねない事態となったのである。

その一方で, 政権側は苦戦を強いられていた。2007 年下院選挙においてそのピークを経験 して以降,「タンデム」時代に入ってからの与党「統一ロシア」は, 次第に集票力を失いつつあっ た。低調な選挙キャンペーンの中で事態をより一層困難にしたのは, 2011 年 9 月 24 日, プー チンが 2012 年 3 月の大統領選挙に出馬し, メドヴェージェフが首相にスライドするといらポ ストの交換が明らかにされたことであった。プーチンの再登板とのものは完全に想定外だった わけではないが，ポストの交換は少なからぬ有権者から反発を導いたのである。

このような状況で行われた 2011 年下院選挙の結果は, 政権側の予想以上の苦戦に特徵付け られた。それを象徵したのが，与党「統一ロシア」の不振であった。同党の得票率は前回の 2007 年選挙と比較して 15 ポイント下がり，50\%をわずかに下回った。「統一ロシア」の議席 は改選前の 315 議席から 238 議席へと低下し, 過半数の 226 議席は上回ったものの, 憲法的法 律等の制定に必要な 3 分の 2 を上回ることはできなかった。この選挙結果は, 政権に対する潜 在的な不満が想定以上に強かったことを示唆するものであった。

そして政権にとってょり危機的であったのは, 反体制派の活動が, 下院選挙後の選挙不正疑 惑をトリガーとして抗議運動へと発展したという点である ${ }^{(18)}$ 。選挙の不正の度合いがこの選 挙の時に特に高かったとは考学にくいが，選挙後には「公正な選挙のために」が抗議運動の合 い言葉となった。抗議運動は選挙当日の 12 月 4 日の夜から始まり，その翌日にも行われた。 そして, 選挙後最初の土曜日となった 10 日には, モスクワに抢いて, 10 万人以上とも言われ る大規模な抗議運動へと発展した。これほどの人が集まる抗議運動は「過去 10 年で初」であっ た。また, モスクワ以外の地方に掞いても, 規模こそそれほど大きくはなかったものの, 抗議 運動が実施された。これはまさに, 政治体制の正統性への疑念が拡大寸る事態であった。

この状況は大統領選挙を経ても大きくは变化しなかった。時間が経過するにつれ, 抗議集会

\footnotetext{
】視した共産党は，2010年 12 月の段階で既にこれを批准すべきとする法案を提出していた。共産党の 法案についての紹介は以下 URL を参照。http://20.kprf.ru/. (2016 年 12 月 21 日アクセス，以下同様)

(16) Немцов, Милов 2010.

(17) Левада центр 2012.

(18) 上野 2012, 貝田 2016.
} 
の実施をめぐる政権と反体制派の攻防は厳しさを増し，許可を受けずに集会を開いて当局に拘 束されるといったよらなケースも相次いだ ${ }^{(19)}$ 。その一つのピークとなったのが，プーチンの 大統領就任直前の 5 月 6 日に行われた「百万人の行進」であった。この「百万人の行進」では, ボロートナヤ広場に拈いて警官隊とデモ隊とが衝突した結果，570人が拘束されるといら事態 にも至っている。プーチン大統領の第三期目は，まさに，波乱の幕開けとなったのである。

\section{3 反体制派による政権批判の構造一一政権による反論の難しさ}

この時期に顕著になった反体制派による攻撃は，政権にとっては厄介なものであった。その 主たる理由は，これらの攻撃が，いずれも政治体制の正統性に直結していたといら点に見出す ことができる。政治体制の正統性にかかわる論点は多岐にわたる。まず，2011 年下院選挙に 向から時期において，反体制派の活動によって問題とされたのは污職・腐敗のトピックであっ た。さらに深刻であったのは，下院選挙後には選挙の公正性といら，政治体制の正統性そのも のにかかわる論点が争点化し，さらには抗議運動にまで発展したことであった。かつての「カ ラー革命」の経験が示す通り, 選挙後の抗議運動は政治体制の正統性を摇るがしかねない事態 であった ${ }^{(20)}$ 。

それに加えて重要なのが，こうした政治体制の正統性にかかわる論点が，反体制派によるポ ピュリスト的な言説の重要な構成要素となっていたといら点である。この点に関しては,ナヴァ リヌィの言説を分析したラッシラが興味深い議論を展開している ${ }^{(21)}$ 。ラッシラによれば，ナ ヴァリヌィは政権の公的なディスコースに拈いてしばしば用いられる「法の支配」「愛国主義」, 「国家の尊厳」などのキーワードを自らも用いながら，それを換骨奪胎する形で政権への批判 を繰り広げた。反体制派は，腐敗・污職をエリート，そしてクレムリンと結びつけ，「法の支配」 =「我々二一般の人々」=「愛国主義または国家の尊厳」を対置させるといらポピュリスト的 な批判の構図を作り出すに至ったのである（図 1)。

このように, 政治体制の正統性にかかわる論点と, ポピュリスト的な政権批判とが重なり合っ たことは，政権側のイニシアチヴによる反論を困難にした。特に重要なのは，反体制派による 批判の中では, 政権側が「法の支配」の対極に置かれ, 常に「我々二一般の人々」の側に正義

図 1 ナヴァリヌィの言説構成

表現容

腐敗 = エリート = クレムリン

内的境界線

$$
\begin{aligned}
& \text { 法の支配 }=\text { 我々・＝愛国主義 } \\
& \text { 一般の人々 国家の尊厳 }
\end{aligned}
$$

出典) Lassila 2016, 127.

\footnotetext{
(19) この間に行われた抗議運動, カウンターデモ, そして拘束者数については以下を参照。Коммерсантъ Спецпроекты «Протестное поведение», http://kommersant.ru/doc/2021447.

(20) Bunce and Wolchik 2011.

(21) Lassila 2016.
} 
があるという点である。反体制派側のロジックに基づけば，自らが「法の支配」を無視してい る政権側にはそもそもその資格がないということになる。政権側が何らかの対応を試みても， それはほとんど説得力を持たない。

抗議運動が始まると, 政権側はまず，一定の自由化に応じた。この点においての政権の対応 は迅速であった。12 月 15 日に行われた「プーチンとの対話」に沶いて, プーチン首相は初め て行政府長官選挙の復活に言及した ${ }^{(22)}$ 。そして, 12 月 22 日付の大統領教書においては, 政党 法の要件緩和, 2004 年に廃止されていた知事の公選制の復活, 下院選挙が全議席を比例区で 選出する方式から半数を小選挙区で選出するかつての方式の復活といった制度改革が宣言され た ${ }^{(23)}$ 。これは, 抗議運動を受けて政権から提示された一定の譲歩であったが，反体制派から のポピュリスト的な批判の構図とのものを覆すには至らなかった。

また，政権側の説得の試みが，かえって反体制派側からの反発を導いた面もある。プーチン 首相は, デモの直後から, 抗議運動を行らこと自体は問題ないが, 抗議運動に参加する人々は 法律を守るべきである，との立場をたびたび表明していた。すなわち，人々が自分の意見を表 明することは正常であり, むしろ歓迎されるべきでもあるが, すべての参加者とすべての政治 勢力は法律の範囲で行動しなければならない, といらのである ${ }^{(24)}$ 。しかし，このよらな説得 の試みは，自らの首を絞めか称ないものでもあった。なぜなら，反体制派の側のロジックに従 えば,「法の支配」に反しているのはもしろ政権の側であるといら反論を導きかねないためで ある。

その例として，2012 年 5 月の抗議運動にかかる規則の厳格化をめぐる応酬を挙げることが できる ${ }^{(25)}$ 。この法案は抗議運動に対する規制を強めるとして, 反体制派のみならず, 議会内 の野党からも強い批判を呼び起こすことになったが, この法案をめぐる議論の際も, 法案の提 出者は, これまでの政権側の論理を踏襲して, 抗議運動の参加者たちも法律に従うべきである との見解を示した。これに厳しい反論を加えたのが，共産党のオリガ・アリーモワ議員（サラ トフ州選出）であった ${ }^{(26)}$ 。

「もし権利の保護とすべての市民の法の下での平等を取り上げるのであれば，不自然な理由 で抗議運動の実施を禁止する役人には何百万ルーブル——しくはドルかもしれないが— もの罰金や社会奉仕活動は科されないのか？……〈中略〉……ラトフでは野党が中央広場 で抗議運動をしょうとすると雪が運び込まれる。『統一ロシア』のデモの際には雪は撤去さ れるが，その翌日には再び雪でいっぱいになる。役人に対しても，抗議運動を組織し参加す る人たちと同じょらに罰が与えられるべきではないのか？」 (27) $^{2}$

(22) Стенограмма программы “Разговор с Владимиром Путиным. Продолжение, https://rg.ru/2011/12/ 15/stenogramma.html/.

(23) 上野 2012 .

(24) Стенограмма программы “Разговор с Владимиром Путиным. Продолжение.

(25) 成立した法律は前注 4 を参照。同法案は 5 月 10 日に下院に送られ，2012 年 5 月 22 日に第一読会， 6 月 5 日に第二読会, 6 月 6 日に第三読会を通過した。

(26) 議会内の野党は厳密には本稿で定義する「反体制派」には属さないが，この時点に拈いては議会内の 野党も政権に対して敵対的な態度をとっていた。

(27) 2012 年 5 月 22 日の下院審議中の発言。Государственная Дума. Стенограмма заседаний. Том 5 (220), 2012 год, 50. 
この発言からは，先の反体制派のポピュリスト的な批判の構図を見出すことができる。すな わち，「法の支配」に反しているのはむしろ当局の方であって，彼らには「我々二一般の人々」 に対して法律の遵守を求める資格はない，といら反論である。反体制派による批判の構造が一 定の力を持っている状況に打いては，反体制派を説得しょらとする政権側の試みは，むしろ返 す刀で反体制派からの攻撃材料にもなりらるのである。

以上の検討から, 政治体制の正統性に傷がついた状況に括いて, 政権側がそれを挽回するた めに何らかのイニシアチヴを採用したとしても，ポピュリスト的な批判そのものを覆すことは ほとんど不可能であるどころか，かえって反体制派からのさらなる攻撃を導きか补ないことが 明らかになった。反体制派が政治体制の正統性にかかわる論点を取り上げ，ポピュリスト的な 批判を繰り広げたことは, 政権のイニシアチヴによる反論が困難な状況を導いた。

\section{4 政権による事態収拾の試み一一体制派の「隔離」}

抗議運動が拡大の一途をたどる中で，政権はとれを鎮静化させる必要性に迫られた。もっと も, 特に翌年 3 月 4 日に予定されていた大統領選挙に至るまでは, 秩序回復の必要性が訴光ら れた一方で，政権の側も手を出しか祘ていた面がある。そのような中で，政権にとっては，言 説のレヴェルに捛いて反体制派を囲い込み，その影響力の拡大を防ぐことが重要な意味を持っ た。政権は, 反体制派がごく一部の異端であるとのレッテルを貼ることにより, 彼らへの支持 の拡大を食い止めようとした。

最初に採用されたのが, 抗議運動の激化は外国の内政干渉の帰結であり, 抗議運動の組織者 は外国の資金を使ってロシアに颃ける政情の不安定化を目指しているとする論法であった。こ れはロシアにとっては目新しいものではなく, 近い事例としては, 「カラー革命」の際にも同 様のレトリックが啇用されていた。その初期の例として, 抗議運動が始まった直後の 12 月 7 日の段階でのプーチンの発言を挙げることができる。「全ロシア人民戦線」の会合に出席した プーチンは, 米国のヒラリー・クリントン国務長官が野党活動家に「シグナル」を与えたと発 言し，野党活動家らが「このシグナルを聞き，米国国務省の支援を受けて活発な活動を開始し た」と述べたのである ${ }^{(28)}$ 。その後, このテーマは政権によって組織された集会に拈いてもた びたび強調されることになる。例えば，2012 年 2 月 5 日に行われたポクロンナヤの丘での政 権側の集会は「アンチ・オレンジ」と銘打たれた ${ }^{(29)}$ 。同集会に打いては, 抗議運動の参加者 たちは外国から資金を受け取っているといった，欧米諸国による内政干渉への警戒感が前面に 出された。

政権は当座の抗議運動が沈静化した後も「反欧米レトリック」を強化し，それが公的なディ スコースを構成するよらになっていった。その典型的な例として挙げられるのが，2012 年 7 月の「外国エージェント」法である ${ }^{(30)}$ 。同法は，外国から資金を受け取ったNGO に対し，外

(28) Vladimir Putin accuses Hillary Clinton of encouraging Russian protests, https://www.theguardian.com/ world/2011/dec/08/vladimir-putin-hillary-clinton-russia.

(29) Митинг на Поклонной. Как это было, http://www.utro.ru/articles/2012/02/04/1026695.shtml\#adimage-0.

(30) Федеральный закон от 20 июля 2012 г. N 121-Ф3 “О внесении изменений в отдельные законодательные акты Российской Федерации в части регулирования деятельности некоммерческих организаций, выполняющих функции иностранного агента” Российская газета, 23 июля 2012 г. 
国エージェントとしての登録を義務付け，それまでよりも財政面等の統制を強化するといら内 容であった。2012 年 12 月に成立したいわゆる「ディーマ・ヤコヴレフ」法 ${ }^{(31)}$ なども同様で ある。同法により，人権侵害に関与，またロシアの国外でロシア国民に対する犯罪に関与した アメリカ国民に対し，ロシアへの入国を禁じるとした。そして同法により，アメリカの国民・ 組織から金銭的支援を受けている，もしくは，ロシア連邦の利益に脅威を与えらる政治活動に 関わる非政府組織のロシア領土での活動が停止できることになった。

また，「反欧米レトリック」とは位相がやや異なるが，政権側が，外国の干渉以外にも保守 主義・愛国主義などの様々な要素を動員することにより, 抗議運動の参加者と, プーチン支持 の「多数派」とを分離するフレーミングを行ったことも指摘されている。このようなフレーミ ングが前面に出たケースとしてしばしば挙げられるのが, 女性のパンクバンドであるプッシー・ ライオットのパフォーマンスをめぐる裁判であった ${ }^{(32)}$ 。教会の腐敗やプーチン体制への批判 を展開していた同バンドは, 2012 年 2 月 21 日のモスクワの救世主大聖堂に拈けるパフォーマ ンスの後で逮捕され，裁判が進められた。この裁判では，バンドのメンバーらは教会を冒瀆す る一部の過激派として描き出され，さらにそれが国民にも受け入れられた例とされる。

ただし，これらのレトリックが反対派からの政権批判を避けるといら点においてどの程度有 効だったのかに関しては慎重な検討が必要である。まず，抗議運動に対して外国からの干渉を 強調する見方はそれほど浸透してはいなかったと言える。2012 年 3 月から 4 月にかけ，米国 の世論調査機関ピュー・リサーチ・センターによって行われた調査によれば, この調査によれ ば，西側が抗議運動に影響を与えたと考えている回答者の割合は $25 \%$ であった一方， $58 \%$ の 回答者が，抗議運動は人々の不満の表明であると答えている ${ }^{(33)}$ 。この調査結果は, 反体制派 による政権批判には一定の理由があると考えられていたことを示している。政権は西側諸国を 引き合いに出すことによって抗議運動のイメージ低下を目指したが，それがとのまま人々に受 け入られたとは言い切れないのである。

また，反体制派を「隔離」する試みもそれほどうまくいったわけではない。なぜなら，反体 制派は, むしろナショナリズムの傾向を強く持っていたためである。リベラル派と呼ばれる政 治家の中でも, 特にナヴァリヌィは愛国主義的な傾向が強い人物であった ${ }^{(34)}$ 。抗議運動の支 持者に関しても，権威主義・民族ナショナリズム的な傾向が強かったとの指摘もある ${ }^{(35)}$ 。プッ シー・ライオット事件の際にも, 確かに一部のリベラル派の政治家は同バンドを擁護したが, ナ ヴァリヌィらはむしろ否定的な態度を示していた ${ }^{(36)}$ 。この時期の政権と反体制派の関係は, 反 欧米, また, 伝統や保守的な価值観の強調といった要素によって割り切れるものではなかった。

ここまでの経過から明らかになるよらに，2011 年末から 2012 年初頭にかけての時期に打い て, 政権にとって反体制派による政権批判をかわすことはとれほど容易ではなかった。選挙不 正に対する批判は比較的早い段階で雲散霧消したものの, 政府高官の污職疑惑や反対派への抑

(31) Федеральный закон от 28 декабря 2012 г. N 272-Ф3 “О мерах воздействия на лиц, причастных к нарушениям основополагающих прав и свобод человека, прав и свобод граждан Российской Федерации" Российская газета, 29 декабря 2012 г.

(32) Smyth and Soboleva 2013, Sharafutdinova 2014.

(33) Pew Research Center 2012.

(34) Laurelle 2014.

(35) Chaisty and Whitefield 2013.

(36) Навальный 2012. 
圧など，政治体制の正統性に直結する問題は残されており，反体制派はこれらの問題に対して も政権側と「我々二一般の人々」とを対置させ, 政権に対する批判を繰り広げる余地があった。

\section{5 政権による批判の「先回り」一腐敗したエリートをめぐるポピュリスト的応酬}

選挙不正をめぐる不満が一段落し, 抗議運動が沈静化した後, 反体制派にとって特に大きな 意味を持ったのが污職批判であった。これはもともと反体制派が熱心に取り組んできたテーマ であるが, 次第に抑圧が強まる中でも, 反体制派らは次々と政府高官のスキャンダルを暴き出 した。これはプーチン大統領自身にも抢よんだ。ネムッォフらは，2012 年 8 月に「『ガレ一船 の奴隷』の生活」といら冊子を出し，プーチン大統領の生活がいかに贅沢かを暴露した ${ }^{(37)}$ 。 こうした豪華な生活はロシアに扣ける日常とはかけ離れたものであり，「我々二一般の人々」 をクレムリンと対置させる上では格好の題材であった。

その一方で, 政権にとっては好ましくない状況が続いていた。2012 年の比較的早い段階で は抗議運動が沈静化していたものの，プーチン大統領の支持率は低迷したままであった。さら に，反体制派から寄せられる批判との関連で言えば，プーチン大統領のイメージがそれ以前よ りも悪化していたといら点が重要である。レヴァダ・センターの調査によれば, 2012 年以降, プーチン大統領がオリガルヒや大企業やシロヴィキ, 官僚の利益を代表していると回答した人 の割合が増加した一方, 中間層や一般の人々の利益を代表していると回答した人の割合は低下 した（表 1)。

腐敗・污職への批判は反体制派による政権の正統性批判の構図と直結していただけでなく, センセーショナルで人目を引きやすいという特徴があった。ブログで政府高官の污職疑惑が取 り上げられる際にはその政府高官の私生活も暴かれるのが常であり，そこにはゴシップ的な要 素も多分に含まれていた。調査の時期はやや後になるが，2013 年 3 月の時点で，ブロガーた ちの反腐敗運動を支持すると答えた回答者の割合は $63 \%$ に達しているとの調査結果があ る ${ }^{(38)}$ 。抗議運動が一段落したとはいえ未だに支持率の回復には至っていなかった政権として は, 反体制派によって熱心に行われた腐敗批判をただ静観しているわけにはいかない状況で あったと言える。

2012 年夏頃から本格化した公務員の海外に打ける銀行口座の保有禁止に向けた動きは, ナ ショナリズムの強化, またクレムリンによるエリートへの統制強化の第一歩としてしばしば取 り上げられる事象であるが ${ }^{(39)}$, 政権と反体制派のポピュリスト的な言説をめぐる攻防という 文脈に括いても重要な意味を持っている。公務員の海外に打ける財産保有は，反体制派による 腐敗批判に打いては必ずと言っていいほど触れられる論点であった。なぜなら, 腐敗したエリー トが，口シアの富を不正に蓄財して豪華な生活を楽しんでいることに加え，それを安全な海外 へと逃避させているといらイメージは,「我々二一般の人々」とエリートとの鋭い対峙を強調 するものであったためである。公務員の海外銀行口座保有禁止に向けた動きは, クレムリン自 らが腐敗したエリートにメスを入れることにより, 反体制派の批判の構図を覆そらとする試み

(37) Немцов, Мартынюк 2012. これは, プーチン大統領が第二期目を終えた 2008 年の大記者会見に拈いて, 自分の働きぶりを振り返って「ガレ一船の奴隷のように働いた」とした発言を㧖ったものである。

(38) Левада центр 2013а.

(39) Morozov 2013. 
表 1 レヴァダ・センターによるプーチン大統領についての調査

質問 : プーチン大統領はどの層の利益を代表していると思らか?

（複数回答，回答者の割合，\%）

\begin{tabular}{|l|c|c|c|c|}
\hline & 2007 年 8 月 & 2011 年 1月 & 2012 年 1月 & 2013 年 3 月 \\
\hline エリツィンの取り巻き & 13 & 10 & 15 & 13 \\
\hline オリガルヒ, 銀行家, 大企業 & 18 & 26 & 36 & 36 \\
\hline 大企業の指導者層 & 13 & 18 & 21 & 18 \\
\hline 国家官僚・官僚機構 & 19 & 24 & 26 & 27 \\
\hline シロヴィキ & 39 & 31 & 37 & 35 \\
\hline 文化・科学エリート & 10 & 10 & 9 & 7 \\
\hline 中間層 (平均以上の所得) & 31 & 26 & 27 & 18 \\
\hline インテリ & 10 & 10 & 8 & 6 \\
\hline 一般の人々 & 24 & 20 & 18 & 12 \\
\hline 漏れなく全員 & 12 & 10 & 7 & 10 \\
\hline わからない & 13 & 13 & 9 & 6 \\
\hline
\end{tabular}

出典) Левада центр (2013b) より一部拔粋。

であったと解釈できる。

このプロセスに掞いて，政権は，それまでの反体制派による政府高官への批判のレトリック をそのままの形で採用した。プーチン大統領は，2012 年 12 月の大統領教書に扔いて同法案へ の支持を訴えた際に，「ロシアの幸福について大声で語りながら自分の財産，資金を国外に持 ち出そうとする官僚や政治家をどらやって信用すればよいといらのだろらか？」と述べている が, これはまさにその例である ${ }^{(40)}$ 。最終的に, 公務員の海外に打ける財産保有を禁じる法律 は2013 年 5 月に成立した ${ }^{(41)}$ 。この法律により, 高級公務員抢よびその配偶者・未成年の子に よる海外の口座保有，株式保有等が禁止されるに至った。

さらに，政権側は，反体制派による提案をそのまま先取りするようにもなった。その様子を よく示しているのが, 公務員による高級車の購入問題である。この問題は国家による調達の基 準価格の設定に関わる論点であるが，これが政権と反体制派との一つの論争点となったのは, これ自体が非常にポピュリスト的なテーマであったためである。下院の審議において「統一口 シア」のヴャチェスラフ・ルィサコフ議員が自ら語っている通り,「公務員がいかに高額な家 具や日用品を買打らと，我々はそれを知りょうがない。しかし，自動車は全員の目に見えるの で憤慨を招きやすい」のである ${ }^{(42)}$ 。

(40) Послание Президента Федеральному Собранию от 12 декабря 2012 года., http://kremlin.ru/events/ president/news/17118.

(41) Федеральный закон от 7 мая 2013 г. N 79-Ф3 “О запрете отдельным категориям лиц открывать и иметь счета (вклады), хранить наличные денежные средства и ценности в иностранных банках, расположенных за пределами территории Российской Федерации, владеть и (или) пользоваться иностранными финансовыми инструментами," Российская газета, 14 мая 2013 г.

(42) 2013 年 11 月 22 日の下院審議中の発言。Государственная Дума. Стенограмма заседаний. Том 23 (238), 2013 год, 528-529. 
この自動車購入額の問題を取り上げたナヴァリヌィは，連邦政府から補助金を受け取ってい る地方に打いても知事らが高額な自動車を購入していることへの批判を展開した ${ }^{(43)}$ 。この問 題は, 2013 年 6 月, 「ロシア社会イニシアチヴ」のサイト上に括いて提起された ${ }^{(44)}$ 。ナヴァリ ヌィは，国家機関による高額な自動車購入には合理的な理由がないとし，納税者の利益を守る ため, 高級車の購入額を 150 万ルーブルに制限することを提案した。この提案は多くの人の注 目を集め，同サイトに执いて 10 万以上の署名を獲得した。

このような反体制派からのイニシアチヴに対し，政権はそれをある意味では「横取り」する 対応を取った ${ }^{(45)}$ 。まず, 政府の作業グループは, ナヴァリヌィの提案は法案として審議され るべき性格のものではないとの結論を出した。その一方で, 2013 年 7 月, 与党の議員らによっ て関連する法案が下院に提出された ${ }^{(46)}$ 。これは, 高級車の購入額の上限こそ 300 万ルーブル と高めに設定されていたものの, ナヴァリ又ィの提案と酷似した法案であった。この法案の審 議のプロセスも, 反体制派のレトリックを踏襲する形で進んでいった。11月22日に行われた 同法案の審議に際し, 法案を提出したルィサコフは, ナヴァリヌィと全く同じょらに,「補助 金を受け取っている地方ですら高い自動車を購入しているといら状況はモラルを欠いている」 として，地方への批判を展開したのである( ${ }^{(47)}$ 。これは，政権による反体制派の批判の先取り にほかならなかった ${ }^{(48)}$ 。

政権の「先回り」は, 反体制派による政権批判の余地を狭めることになった。まず，自動車 購入額の上限設定問題のように, 反体制派の批判が, 政権による論点の横取り等によって無効 化されたといら点が挙げられる。それに加えて, 政権側が腐敗したエリートにメスを入れる姿 勢を示したことは，国民に対しても一定のアピールとなった。クリミア併合に伴らプーチン大 統領の支持率上昇を割り引いて考光る必要はあるものの，2014 年 4 月に行われたレヴァダ・ センターの調査によれば，「プーチンがロシアの富を自らの利益のために用いる官僚と戦って いる」と答えた回答者の割合はその前年の $49 \%$ から $60 \%$ に増加している ${ }^{(49)}$ 。クレムリン自 身が腐敗したエリートと対峙する構図が前面に出れば，「腐敗したエリートニクレムリン」を 「我々二一般の人々」と対置させる反体制派の批判も精彩を欠くことになる。このようにして, 反体制派は言説のレヴェルに㧤いても次第に追い詰められていったのである。

(43) Фонд борьбы с коррупцией, отчет за 2014 год, https://navalny.com/p/4303/.

(44)「ロシア社会イニシアチヴ」サイト, https://www.roi.ru/759/.「ロシア社会イニシアチヴ」とは政策の 提言を行らインターネット上のプラットフォームで，そこで 10 万以上の署名が集まると政府によっ てその提案が検討されることになっている。

(45) この間の経緯については, Макутина 2013 を参照。

(46) Законопроект № 310244-6 О внесении изменений в некоторые законодательные акты Российской Федерации (в части ограничения прав получателей бюджетных средств и юридических лиц с государственным участием на закупку легковых автомобилей высокой стоимости). http://asozd2.duma. gov.ru/main.nsf/\%28SpravkaNew\%29? OpenAgent\&RN=310244-6\&02.

(47) Государственная Дума. Стенограмма заседаний. Том 23 (238), 2013 год, 528-529.

(48) この法案の審議は第一読会でストップし, これが単なるパフォーマンスに過ぎなかったことを印象づ ける展開となった。

(49) もっとも, 反腐敗キャンペーンの成功を信じる人が増えたわけではない。同調査においては, 「プー チンは腐敗との戦いを続けるが，ロシアの腐敗は根絶不可能なので，成功することはすずないだろう」 と答えた回答者の割合も増加した（Левада центр 2014）。 
本稿に捛いては, 政権と反体制派の間で繰り広げられた言説のレヴェルの応酬に注目して「反 体制派」の時代を振り返った。本稿からはまず, 反体制派による政治体制の正統性への攻撃が, 反体制派のプレゼンス維持を可能にしたことが明らかになった。ひとたび政権の正統性に疑義 が生じると，政権側のイニシアチヴでそれを覆すことは至難の業となるためである。しかし， 本稿の検討からは，時間が経つにつれ，政権側が次第に反体制派の批判の構図をそのまま取り 込むよらになっていったことが示された。本稿に扮いて注目した言説レヴェルの応酬は，現職 が圧倒的な優位に立つ政治体制において反体制派が一定のプレゼンスを維持した理由，にもか かわらず，反体制派の活動領域が次第に狭められていった理由の双方をらまく説明する。

この一連の経過は, 政権と反体制派の一筋縄ではいかない関係を考える上でも示唆的である。 政権側は確かに様々な手段とリソースを有していた。抗議運動に対する締め付けを強める，ま た，反体制活動家に対して家宅捜索を行って直接的に压力をかけるなど，様々な方法で「口を 封じる」ことは可能であり, 実際に, こうした様々な方法が実施されもした。しかし, 反体制 派がブログといら手段を用いて政権批判を展開する中で，これらの手段だけでは批判を押さえ 込むことはできなかった。最終的には政権自らが反対派の批判を先回りすることによって対処 が試みられたという点は, 政治体制の正統性に対する批判への政権側の対処がいかに難しかっ たかをよく示している。

また，本稿からは，この「反体制派の時代」に颃いても，污職・腐敗批判をはじめとしたポ ピュリスト的な争点が大きな役割を果たしていたことが明らかになった。これは政権側と比較 すれば圧倒的に不利な立場にあった反体制派が勢いづくことを可能にもしたが，政権と反体制 派との間でのポピュリスト的な言説の奪い合いを経て, 次第に政権側が反体制派の活動領域を 侵食していくことにもつながった。本稿に拈いて明らかにした一連の経過は，自らを一般の 人々の味方と位置づけ，「敵」を一般の人々の利益を害する悪として描き出すポピュリスト的 な言説構成がロシアの政治に招いて幅広く適用されていること, そして, それが市民からの支 持調達预よび「敵」への攻撃に扔いて一定の効果を持っていたことを確認するものである。

最後に，反体制派のその後の展望について触れておくことにしたい。2014 年 3 月のクリミ ア併合を経て, ロシアに打ける政治状況は更なる変化を迎えた。2014 年 3 月を境としてプー チン大統領の支持率はかつてない水準に跳水上がり, 現在に至るまで $80 \%$ 以上を維持してい る。このような状況が現れる中で, 既にそれ以前から精彩を欠くょうになっていた反体制派は いよいよ力を失ったようにも見光る。しかし, 反体制派が全く無意味な存在になったわけでは ない。クリミア併合の余波として問題となった欧米からの制裁と「逆制裁」をめぐる問題, そ して 2014 年末からの原油価格の下落といった状況が現れる中で, 潜在的な不満材料はむしろ 増えつつある。そのような中で, 反体制派の活動は再び力を持つ可能性がある。とりわけ, 2017 年 3 月のメドヴェージェフ首相の污職疑惑が反污職デモへとつながったことからも明ら かになるように, 政府高官の污職の問題が尽きることはなく，この点に関しては依然として反 体制派が大きな役割を果たしている。2011 年から 2013 年にかけての経験は, こうした批判を 代弁する反体制派が登場した場合には幅広い支持を集める可能性があること, また反体制派に よるポピュリスト的な政権批判への対応が非常に困難であることが指摘できる。愛国主義動員 の強化とは別に，こうした日常的な不満の高まりがどのような形で媒介されるのか，そしてそ 
れに対して政権がいかなる対処をしていくのかといら問題は，今後のロシア政治を観察する上 での一つの焦点であり続けるものと考兄らる。

\section{参 考 文 献}

上野俊彦（2012）「下院選から大統領教書，そして改革へ？—-2011 年 12 月下院選に対する「不正のない 選挙のために」運動の意味とその影響—」『ロシアに拈けるエネルギー・環境・近代化』日本国際 問題研究所。

宇山智彦（2014）「変質するロシアがユーラシアに広げる不安：進化する権威主義，迷走する『帝国』』現 代思想』2014 年 7 月号。

貝田真紀（2016）「現代ロシアに打ける反政府勢力と社会運動—- 2011 年から 2013 年にかけての社会運動 を事例に—」『ロシア・ユーラシアの経済と社会』1001 号。

Левада центр (2012) «Единая Россия» не может избавиться от ярлыка «партией жуликов и воров» ее считают все больше россиян.

http://www.levada.ru/2012/07/04/edinaya-rossiya-ne-mozhet-izbavitsya-ot-yarlyka-partiej-zhulikov-i-vorov-eeschitayut-vse-bolshe-rossiyan/. (2016 年 12 月 21 日アクセス，以下同様)

Левада центр (2013a) Россияне о борьбе с коррупцией, независимости депутатов и новых законопроектах о недвижимости и счетах парламентариев.

http://www.levada.ru/2013/04/03/rossiyane-o-borbe-s-korruptsiej-nezavisimosti-deputatov-i-novyh-zakonoproektah-o-nedvizhimosti-i-schetah-parlamentariev/.

Левада центр (2013b) Владимир Путин: год после избрания Президентом. http://www.levada. $\mathrm{ru} / 2013 / 04 / 11$ /vladimir-putin-god-posle-izbraniya-prezidentom/

Левада центр (2014) Коррупция и бюрократизм. http://www.levada.ru/2014/05/19/korruptsiya-ibyurokratizm-2/.

Немцов, Борис, Владимир Милов. (2010) Путин. Итоги. 10 лет: независимый экспертный доклад. http://www.putin-itogi.ru/doklad/.

Немцов, Борис, Леонид Мартынюк (2012) Жизнь раба на галерах. Дворцы, яхты, автомобили, самолеты и другие аксессуары. М. http://www.putin-itogi.ru/rab-na-galerah/

Макутина, Мария (2013) Петиция Навального не доехала до Думы, Газета.ru, https://www.gazeta.ru/ politics/2013/09/10_a_5647137.shtml.

Навальный, Алексей (2012) “Про пусси райотс,” 7 марта 2012 г. http://navalny.livejournal.com/690551.html.

Bunce, Valerie J. and Sharon L. Wolchik (2011) Defeating Authoritarian Leaders in Postcomunist Countries, Cambridge University Press.

Chaisty, Paul and Stephen Whitefield (2012) "The Effects of the Global Financial Crisis on Russian Political Attitudes," Post-Soviet Affairs 28 (2).

Gel'man, Vladimir (2015a) "The Politics of Fear: How the Russian Regime Confronts Its Opponents," Russian Politics \& Law, 53 (5-6).

Gel'man, Vladimir (2015b) "Political Opposition in Russia: A Troubled Transformation," Europe-Asia Studies 67 (2).

Greene, Kenneth F. (2002) "Opposition Party Strategy and Spatial Competition in Dominant Party Regimes: A Theory and the Case of Mexico," Comparative Political Studies 35 (7).

Lanskoy, Miriam and Elpeth Suthers (2013) "Outlawing the Opposition," Journal of Democracy 24 (3).

Lassila, Jussi (2016) "Aleksei Naval'nyi and Populist Re-ordering of Putin's Stability," Europe-Asia Studies 68 (1).

Laruelle, Marlene (2014) "Alexei Navalny and Challenges in Reconciling 'Nationalism' and 'Liberalism'," PostSoviet Affairs, 30 (4).

Morozov, Viatcheslav (2013) "Nationalization of the Elites and Its Impact on Russian Foreign Policy," PONARS Policy Memo, No. 251, June.

Pew Research Center (2012) Russians Back Protests, Political Freedoms and Putin, Too

http://www.pewglobal.org/2012/05/23/chapter-2-reaction-to-presidential-election-protests/.

Sakwa, Richard (2014) Putin Redux: Power and Contradiction in Contemporary Russia, Routledge.

Sakwa, Richard (2015) “Questioning Control and Contestation in Late Putinite Russia," Europe-Asia Studies 67 (2).

Sharafutdinova, Gulnaz (2014) "The Pussy Riot Affair and Putin’s Démarche from Sovereign Democracy to Sovereign Morality," Nationalities Papers, 42 (4).

Smyth, Regina and Irina Soboleva (2013) "Looking Beyond the Economy: Pussy Riot and the Kremlin's Voting Coalition," Post-Soviet Affairs 30 (4). 
White, David (2015) "An Uphill Battle: Maintaining Political Opposition in the Context of Russia's Nationalist Turn," Russian Analytical Digest No. 166.

（付記）本研究は, 平成 $28 \sim 30$ 年度科学研究費補助金若手研究（B）「現代ロシアに括ける政 治体制と選挙 : 選挙の公正性をめぐるポリティクス」(課題番号 : 16K17058）の研究 成果の一部である。本論文の執筆にあたっては, 中田瑞穂 (明治学院大学), 溝口修平 (中京大学) の両氏から貴重なコメントをいただいた。記して感謝したい。 